\title{
Preliminary studies on the bacterial flora of faeces taken from foals, from birth to twelve weeks. Effect of the oral administration of a commercial colostrum replacer.
}

\author{
V. Julliand ${ }^{1}$, A. de Vaux', L. Villard ${ }^{2}$ and Y. Richard ${ }^{2}$ \\ ${ }^{1}$ Laboratoire de Microbiologie anaérobie, Unité associée ENESAD-INRA, Dijon, France \\ 2 Laboratoire de Microbiologie, ENVL, Marcy l'Etoile, France
}

\begin{abstract}
Summary
The faecal microflora of 18 normal, two month-old foals was composed of aerobes and facultative anaerobes, mainly Enterococci (10 ${ }^{7}$ CFU/g of faeces) and Lactobacilli $\left(10^{8} \mathrm{CFU} / \mathrm{g}\right)$ and strict anaerobes, cellulolytic bacteria $\left(10^{5} \mathrm{CFU} / \mathrm{g}\right)$ and Clostridia $\left(10^{4} \mathrm{CFU} / \mathrm{g}\right)$. At this early age different bacterial strains colonized the gut according to a specific sequence which could be modified by the oral administration of a commercial colostrum replacer. The faecal microflora of 5 foals fed this colostrum at birth and once every two weeks during the first three months appeared to contain less cellulolytic bacteria and no Lactobacilli. The small number of foals treated limited our interpretation.
\end{abstract}

keywords: foals, faeces, bacteria, colostrotherapy

Vorstudie über die Keimflora im Fohlenkot von der Geburt bis zur zwölften Lebenswoche. Auswirkungen der oralen Applikation eines kommerziellen Kolostrum-Milchaustauschers auf die Keimflora

Die Mikroflora der Kotproben von 18 zwei Monate alten normal entwickelten Fohlen bestand einerseits aus aeroben und fakultativ anaeroben Keimen. Dazu zählten Enterokokken $\left(10^{7} \mathrm{KbE} / \mathrm{g} \mathrm{Kot}\right)$ und Laktobazillen $\left(10^{8} \mathrm{KbE} / \mathrm{g} \mathrm{Kot}\right)$. Zusätzlich wurden Anaerobier in Form von zellulolytischen Bakterien ( $10^{5} \mathrm{KbE} / \mathrm{g}$ Kot) sowie Clostridien (104 KbE/g Kot) nachgewiesen.

Verschiedene bakterielle Stämme besiedeln das Fohlenintestinum in einer spezifischen Sequenz, die durch die orale Applikation von kommerziellen Kolostrum-Milchaustauschern verändert werden könnte. Fünf Fohlen, die Kolostrum-Milchaustauscher nach der Geburt und anschließend im Abstand von zwei Wochen während der ersten drei Lebensmonate erhalten hatten, schienen in ihrer Darmflora weniger zelluloytische Bakterien und keine Laktobazillen aufzuweisen. Unsere Auswertung wurde aufgrund der geringen Anzahl der behandelten Fohlen eingeschränkt.

Schlüsselwörter: Fohlen, Kot, Bakterien, Kolostrumtherapie

\section{Introduction}

The digestive tract of the new-born foal is entirely sterile but is rapidly colonized by diverse maternal and environmental microorganisms; the sequences of bacterial colonization have never been studied. This study would be of great interest from both physiological and pathological aspect in order to better comprehend the fiber degradation in adult horses. In young ruminant animals, the development of successive floras has been determined; the qualitative composition and the means of colonization are partially known, too (Fonty et al. 1987; Anderson et al. 1987). In new-born foals, the qualitative composition of the intestinal flora and its change with time has been studied (Alexander and Davies 1963; Hagiage 1994).

The „Institut du Cheval“ (Station de Pathologie de Ploufragan) conducted a survey of foals in France in 1990. The survey showed that $22 \%$ suffered from immunodeficiency and $49 \%$ got ill and/or died. Today, only serotherapy allows immunodeficient foals to gain immune protection. A therapy using a commercial colostrum replacer could allow the same protection, too; however, the effect of this on the foal's future digestive functions, especially in relation to dietary fibre is not known. Thus the faecal microfloras of treated foals were studied to investigate the possible impact of this therapy on microbial colonization of the foal's gut.

\section{Materials and methods}

\section{The foals}

In Bonnevent, the 13 foals formed one control group (maternal colostrum) whereas in Pompadour they were divided into a control group (5 foals) and in a treatment group (5 foals: commercial colostrum). In the control group, the foals 
had continuous access to maternal colostrum from birth. In the treatment group, the foals were muzzled and deprived

Tab. 1: Foals details

Angaben zu den Fohlen

\begin{tabular}{|c|c|c|c|}
\hline & $\begin{array}{l}\text { NAME OF } \\
\text { THE FOAL }\end{array}$ & $\begin{array}{l}\text { DAY OF } \\
\text { BIRTH }\end{array}$ & $\begin{array}{l}\text { COLOSTRUM } \\
\text { SOURCE }\end{array}$ \\
\hline \multirow{10}{*}{$\begin{array}{l}\text { Stud farm } \\
\text { POMPADOUR } \\
\text { (Corrèze) }\end{array}$} & Spirée & $18 / 05 / 94$ & \multirow[t]{5}{*}{ Commercial } \\
\hline & Princesse & $26 / 05 / 94$ & \\
\hline & Laila & $30 / 05 / 94$ & \\
\hline & Pimpolaise & $14 / 06 / 94$ & \\
\hline & Forcloude & 09/07/94 & \\
\hline & Tulipe & 08/05/94 & \multirow[t]{5}{*}{ Maternal } \\
\hline & Vendoise & $24 / 05 / 94$ & \\
\hline & Diolyne & $29 / 05 / 94$ & \\
\hline & Nommer & $30 / 05 / 94$ & \\
\hline & Loucry & $30 / 05 / 94$ & \\
\hline \multirow{13}{*}{$\begin{array}{l}\text { Stud farm } \\
\text { BONNEVENT } \\
\text { (Orne) }\end{array}$} & Azzouze & $20 / 01 / 94$ & \multirow[t]{13}{*}{ Maternal } \\
\hline & La Nana & $01 / 02 / 94$ & \\
\hline & Tenesse & $02 / 02 / 94$ & \\
\hline & Ruby valley & $10 / 02 / 94$ & \\
\hline & Twiny & $27 / 03 / 94$ & \\
\hline & Tornade & $29 / 03 / 94$ & \\
\hline & Golden & $11 / 04 / 94$ & \\
\hline & Mina & $15 / 04 / 94$ & \\
\hline & Rossa & $19 / 04 / 94$ & \\
\hline & Sakina & $21 / 04 / 94$ & \\
\hline & Vodka & $21 / 04 / 94$ & \\
\hline & Quetch & $23 / 04 / 94$ & \\
\hline & Chipie & $23 / 04 / 94$ & \\
\hline
\end{tabular}

of maternal colostrum, but received instead immediately after their birth and once every two weeks during three months the commercial colostrum replacer (Neocolostrum $\left.^{\circledR}\right)$. This colostrum contained $20 \%$ of natural maternal colostrum from vaccinated mares (tetanus, influenża and rotavirus) and $80 \%$ of serum gamma-globulins from equine. $500 \mathrm{ml}$ were given twice a day either within a bottle or via a naso-gastric tube.

\section{The faeces samples}

Excreted faeces were immediately collected in sterile cans every two weeks from birth to weaning. These cans were mailed in refrigerated boxes to the microbiological laboratory of the Ecole Nationale Vétérinaire de Lyon (ENVL). When possible, the samples were divided and sent, under refrigeration, to the microbiological laboratory of the zoo- technical unit in Dijon (ENESAD-INRA). In each laboratory, samples were stored frozen before analysis.

\section{Faecal microbiology}

The aerobes and facultative anaerobes were studied in the ENVL laboratory and the strict anaerobes were examined in the ENESAD-INRA laboratory.

Most microorganisms in the gut are strict anaerobes and require special cultural techniques (Hungate 1969).

One gram of sample was diluted to $10^{8}$ either in physiological salt solution $(8 \% \mathrm{NaCl})$ for the aero-anaerobes or in a special solution for the strict anaerobes (Bryant and Burkey 1953).

Aerobes and facultative anaerobes were isolated on selective media: Rogosa medium (Lactobacilli), ANC medium (Stapylococci), KF medium (Enterococci) and Hektoën medium (Enterobacteria). After staining, the different isolated strains were identified through their biochemical characteristics: macro-methods in conventional tubes (Bergey's manual, $9^{\text {th }}$ ed. 1994) (Lactobacilli) or micro-methods (Api BioMérieux: Staphylococci, Enterococci and Enterobacteria). The total anaerobes were estimated at $10^{6}$ and $10^{7}$ on rolltubes containing a solid medium (Leedle and Hespell 1980) after $120 \mathrm{~h}$ of incubation at $39^{\circ} \mathrm{C}$.

Cellulolytic flora was estimated at $10^{2}, 10^{3}$ and $10^{4}$ for foals prior to 1 month and at $10^{3}, 10^{4}$ and $10^{5}$ for the older animals, on a specific liquid medium (Halliwell and Bryant 1953) after two weeks of incubation at $39^{\circ} \mathrm{C}$. Clostridia were determined at $10^{5}, 10^{6}$ and $10^{7}$ on a reduced commercial Brain-Heart infusion (Bio-Mérieux) after $120 \mathrm{~h}$ of incubation at $30^{\circ} \mathrm{C}$. To select the clostridia (spore-forming bacteria) the $10^{2}$ dilution was heated at $75^{\circ} \mathrm{C}$ for $10 \mathrm{mi}-$ nutes.

Attempts were made to quantify the fungi using Joblin's technique (1981).

Cellulolytic bacteria and fungi were examined microscopically.

\section{Results}

\section{Aerobic and facultative anaerobic floras}

The aerobes and facultative anaerobes of the control group were composed mainly of Enterococci until 6 weeks and then of Lactobacilli $\left(10^{8} \mathrm{CFU} / \mathrm{g}\right)$. The subdominant bacteria were essentially Enterobacteria and Staphylococci $\left(10^{5}\right.$ CFU/g).

In the treatment group Enterococci remained the most numerically important throughout the study. At 12 weeks, no Lactobacilli were detected. The subdominant floras were equivalent to those found in the control group. (see Tab 2.)

\section{Strict anaerobic floras}

The anaerobes were more numerous in the treatment group than in the control group: up to $10^{9} \mathrm{CFU} / \mathrm{g}$ faeces compared to $10^{8} \mathrm{CFU} / \mathrm{g}$. 
Tab. 2: Numbers of aerobes and facultative anaerobes (CFU/g of faeces)

Anzahl der Aerobier und fakultativen Anaerobier (KbE/g Kot)

\begin{tabular}{|c|c|c|c|c|c|c|c|c|}
\hline & \multicolumn{2}{|c|}{ Enterococci } & \multicolumn{2}{c|}{ Lactobacilli } & \multicolumn{2}{c|}{ Staphylococci } & \multicolumn{2}{c|}{ Enterobacteria } \\
\hline $\begin{array}{c}\text { Timing } \\
\text { weeks }\end{array}$ & $\begin{array}{l}\text { Control } \\
\text { group }\end{array}$ & $\begin{array}{l}\text { Treatment } \\
\text { group }\end{array}$ & $\begin{array}{l}\text { Control } \\
\text { group }\end{array}$ & $\begin{array}{l}\text { Treatment } \\
\text { group }\end{array}$ & $\begin{array}{l}\text { Control } \\
\text { group }\end{array}$ & $\begin{array}{l}\text { Treatment } \\
\text { group }\end{array}$ & $\begin{array}{l}\text { Control } \\
\text { group }\end{array}$ & $\begin{array}{l}\text { Treatment } \\
\text { group }\end{array}$ \\
\hline 0 & $8.10^{8}$ & $6.10^{8}$ & $6.3 .10^{4}$ & $6.3 .10^{4}$ & $1.10^{7}$ & $1.10^{7}$ & $1.10^{8}$ & $3.10^{8}$ \\
\hline 1 & $2.10^{7}$ & $2.10^{7}$ & $3.1 .10^{5}$ & $1.10^{5}$ & $1.10^{7}$ & $1.5 .10^{7}$ & $6.3 .10^{7}$ & $1.10^{7}$ \\
\hline 2 & $5.10^{6}$ & $1.10^{7}$ & $6.3 .10^{5}$ & $3.1 .10^{4}$ & $1.10^{6}$ & $9.10^{5}$ & $3.2 .10^{6}$ & $5.10^{6}$ \\
\hline 4 & $2.10^{7}$ & $5.10^{6}$ & $1.10^{6}$ & 0 & $3.2 .10^{6}$ & $3.10^{6}$ & $4.10^{6}$ & $1.10^{6}$ \\
\hline 6 & $2.10^{7}$ & $1.10^{7}$ & $6.3 .10^{6}$ & 0 & $3.2 .10^{5}$ & $3.5 .10^{5}$ & $3.2 .10^{5}$ & $6.10^{5}$ \\
\hline 8 & $1.10^{7}$ & $1.10^{7}$ & $2.10^{7}$ & $1.10^{4}$ & $1.10^{6}$ & $1.10^{6}$ & $6.3 .10^{5}$ & $8.10^{5}$ \\
\hline 12 & $1.6 .10^{7}$ & $2.10^{7}$ & $1.3 .10^{8}$ & $2.5 .10^{4}$ & $1.10^{5}$ & $2.10^{5}$ & $3.2 .10^{5}$ & $1.10^{5}$ \\
\hline
\end{tabular}

Tab. 3: Numbers of strict anaerobes (CFU/g of faeces).

Anzahl der obligaten Anaerobier (KbE/g Kot)

\begin{tabular}{|c|c|c|c|c|c|c|}
\hline & \multicolumn{2}{|c|}{ Total anaerobes } & \multicolumn{2}{c|}{ Cellulolytic bacteria } & \multicolumn{2}{c|}{ Clostridia } \\
\hline $\begin{array}{c}\text { Timing } \\
\text { weeks }\end{array}$ & $\begin{array}{c}\text { Control } \\
\text { group }\end{array}$ & $\begin{array}{c}\text { Treatment } \\
\text { group }\end{array}$ & $\begin{array}{c}\text { Control } \\
\text { group }\end{array}$ & $\begin{array}{c}\text { Treatment } \\
\text { group }\end{array}$ & $\begin{array}{c}\text { Control } \\
\text { group }\end{array}$ & $\begin{array}{c}\text { Treatment } \\
\text { group }\end{array}$ \\
\hline 0 & $0.3 .10^{8}$ & $1.3 .10^{9}$ & 0 & 0 & $1.10^{6}$ & $4.7 .10^{6}$ \\
\hline 1 & $0.3 .10^{8}$ & $\mathrm{ND}^{*}$ & $2.10^{2}$ & $\mathrm{ND}^{\star}$ & $2.2 .10^{6}$ & $\mathrm{ND}^{*}$ \\
\hline 2 & $2.4 .10^{8}$ & $1.8 .10^{9}$ & $2.4 .10^{4}$ & $1.5 .10^{2}$ & $1.9 .10^{6}$ & $2.8 .10^{6}$ \\
\hline 4 & $3.1 .10^{8}$ & $4.9 .10^{8}$ & $1.10^{5}$ & $0.8 .10^{2}$ & $7.4 .10^{6}$ & $0.3 .10^{6}$ \\
\hline 6 & $\mathrm{ND}^{\star}$ & $0.3 .10^{8}$ & $\mathrm{ND}^{\star}$ & $9.3 .10^{3}$ & $\mathrm{ND}^{\star}$ & $7.8 .14^{5}$ \\
\hline 8 & $3.2 .10^{8}$ & $1.10^{8}$ & $1.9 .10^{5}$ & $1.4 .10^{3}$ & $1.1 .10^{5}$ & $9.4 .10^{4}$ \\
\hline 12 & $\mathrm{ND}^{*}$ & $1.2 .10^{8}$ & $\mathrm{ND}^{*}$ & $6.1 .10^{4}$ & $\mathrm{ND}^{*}$ & $1.10^{4}$ \\
\hline
\end{tabular}

* Unfortunately, the collection and transportation system did not allow a full satisfactory conservation of the samples. This explains the Non Determined (ND) values.

Cellulolytic bacteria seemed slower to establish in the treatment group than in the control group : the count was $10^{2}$ $\mathrm{CFU} / \mathrm{g}$ from weeks four to six and it increased 100 fold reaching, at twelve weeks, $10^{5} \mathrm{CFU} / \mathrm{g}$. When observed with a microscope ( $x 1000$, immersion), most of the cellulolytic bacteria formed long coccal chains similar to Ruminococcus flavefaciens.

The number of Clostridia in the two groups was $10^{6}$ CFU/g during the first six weeks and decreased to $10^{4}$ $\mathrm{CFU} / \mathrm{g}$ thereafter.

No growth could be observed in the Joblin's medium. Direct microscopic examination $(\times 100)$ of $10^{2}$ inoculated tubes showed sporangia either attached to fungal thalli or with no thallus. No zoospores could be detected. So it was not possible to identify the species (see Tab. 3).

\section{Discussion}

It seems that the digestive tract was colonized very early in the control group by bacteria. In the first $24 \mathrm{~h}$, the total faecal microbial population was $10^{8} \mathrm{CFU} / \mathrm{g}$, which is close to the values measured in adult equids (Baruc et al. 1983;
MacKie and Wilkins 1988). In the young ruminants, calves and lambs, the rumen is known to be colonized immediately after birth (Jayne-Williams 1979). At $48 \mathrm{~h}, 10^{9}$ bacteria/ml of rumen contents have been counted and this population was achieved at the end of the first week of life, a level equivalent to that found in adults.

In the samples collected on the day of birth, both aerobes plus facultative anaerobes and strict anaerobes were counted. This early establishment of strict anaerobes in the foal digestive tract has not been recorded before. In the monogastric, in contrast to the ruminant, the digestive tract is colonized by strictly anaerobes only at weaning, except in rabbits (Fonty et al. 1995). Caecal and colonic ecosystems in horses which are monogastric but also herbivorous, showed developments similar to the ruminal ecosystem.

In the young equine, aerobes and facultative anaerobes were more numerous than the strict anaerobes during the first week of life $\left(10^{9}\right.$ and $10^{8} \mathrm{CFU} / \mathrm{g}$ respectively). After this, the ratio tended to equalize staying at $10^{9} \mathrm{CFU} / \mathrm{g}$ at 12 weeks. These findings were different from those known in the young ruminant. In the calf as well as in the lamb, ruminal aero-anaerobes were 10 to 100 times less important 
than strict anaerobes in the second and third weeks, and 10000 times less important at the age of two months ( $\mathrm{An}$ derson et al. 1987; Fonty et al. 1987). These differences could partly be explained by the sampling techniques: faeces were collected under ambient conditions; this allowed the facultative aero-anaerobes to grow more rapidly than they would have done inside the anaerobic digestive tract. It would be of great interest to confirm this explanation by measuring the flora in faeces collected per rectum.

Published informations on the foal faecal microflora (Alexander and Davies 1963) was confirmed in the current study: Lactobacilli are generally more important in the proximal parts of the digestive tract; $E$. coli and coliforms inhabiting the whole digestive tract; Streptococci, producers of lactic acid in the stomach or in the large intestine and the strict anaerobes (Bacteroides and Clostridia), present in the caecum and colon, were found in the foal faeces. The bacterial flora evolved with time and was comparable to that of the adult within 12 weeks (Alexander and Davies 1963; Mackie and Wilkins 1988). It was similar to that found in the piglet or lamb (Smith 1965). This might be explained by the similarity within the digestive tract and the nutrition pre-weaning.

The establishment of cellulolytic bacteria occurred early in the foal digestive tract as well as in that of the calf and lamb rumen. In the first week, 200 cellulolytic bacteria/g of faeces were enumerated. However, this value seemed a lot lower than that for lambs: at the same age, cellulolytic bacteria were present in the lamb rumen at a similar level than in the adult rumen (from $10^{7}$ to $10^{8} \mathrm{CFU} / \mathrm{ml}$ of ruminal content) (Fonty et al. 1987). The low numbers counted in the foal faeces could be also due to the way the samples were collected. The cellulolytic bacteria in the foal digestive tract increased to adult values at the age of two months. This was similar to results obtained with calves (Anderson et al. 1987).

Before foals are fed solid food, cellulolytic bacteria colonized the digestive tract.

The results showed that the repeated administration of commercial colostrum replacer within the first three months of life reduced the numbers of cellulolytical microorganisms and of the Lactobacilli and increased the numbers of total anaerobes during the first two weeks. The commercial colostrum replacer might modify the physicochemical environment of the digestive tract or interact immunologically with lactate producing or cellulolytic bacteria. The consequences on digestion, and particularly fibredigestion, have to be determined. It would be a disadvantage if the Neocolostrum ${ }^{\circledR}$ had a negative impact on microbial populations within the digestive tract in spite of protecting the immunodeficient foal (Bonneau et al., pers. communication).

Interpretation of the results is limited by the small number of foals that were treated with Neocolostrum ${ }^{\circledR}$, and since it was a small part of a larger study, the protocols were not as rigorous as would have been appropriate. Our results require to be confirmed with further experimental work.

\section{References}

Alexander, F. and Davies, M. E. (1963): Production and fermentation of lactate by bacteria in the alimentary canal of the horse and pig. J.Comp.Path.73, 1-8

Anderson, K. L., Nagaraja, T. G., Morill, J. L., Avery, T. B., Galitzer, S. J. and Boyer, J. E. (1987): Ruminal microbial development in conventionally or early weaned calves. A. Anim. Sci.64, 1215-1226

Baruc, C. J., Dawson, K. A. and Baker, J. P. (1983): The characterization and nitrogen metabolism of equine caecal bacteria. $8^{\text {th }}$ ENPS, University of Kentucky, 151-156

Bryant, M. P. and Burkey, L. A. (1953): Cultural methods and some characteristics of the more numerous groups of bacteria in the bovine rumen. J.Dairy. Sci. 36, 205-217

Fonty, G., Gouet, P., Jouany, J. P. and Senaud, J. (1987): Establishment of the microflora and anaerobic fungi in the rumen of lambs. J.Gen. Microbiol. 123, 1835-1843

Fonty, G., Jouany, J. P., Forano, E. and Gouet, Ph. (1995): L'écosystème microbien du réticulo-rumen. In: Nutrition des Ruminantes domestiques.

Jarrige, R., Ruckebush, Y., Demarquilly, C., Farce, M. H. and Journet, $M$. eds. INRA., pp. 299-347

Hagiage, M. (1994): La flore intestinale : de l'équilibre au déséquilibre. Vigot France Ed.

Halliwell, G. and Bryant, M. P. (1953): J.Gen.Microbiol. 32, $441-448$

Hungate, R. E. (1969): A roll-tube method for cultivation of strict anaerobes. In Norris, J. R and Ribbons, D. W. „Methods in microbiology", Academic Press, New York-London 3(B), $117-132$

Jayne-Williams, D. J. (1979): The bacterial flora of the rumen of healthy and bloating calves. J.Appl.Bacteriol. 47, 271-284

Joblin, K. N. (1981): Isolation, enumeration and maintenance of rumen anaerbic fungi in roll-tubes. Appl.Environ.Microbiol. 42(6), $1119-1122$

Leedle, J. A. Z. and Hespell, R. B. (1980): Differential carbohydrate media and anaerobic replica platting technics in delineating carbohydrate utilizing subgroups in rumen bacterial population. Appl. Environ. Microbiol. 39, 709-719

Mackie, R. I. and Wilkins, C. A. (1988): Enumeration of bacterial microflora of the equine gastrointestinal tract. Appl.Environ. Microbiol. 54(9), 2155-2160

Smith, H.W. (1965): The development of the flora of the alimentary tract in young animals. J. Path. 90, 495-513

V. Julliand
A. de Vaux

Laboratoire de Microbiologie anaérobie

Unité associée ENESAD-INRA

26, bd docteur Petitjean

21000 Dijon

France

L. Villard

Y. Richard

Laboratoire de Microbiologie

ENVL

1, avenue Bourgelat

69280 Marcy L'Etoile

France 